\title{
EQUALITAS GENDER (Konsep dan Aktualisasinya dalam Islâm serta Implikasinya atas Rumusan Hukum Islâm)
}

\author{
Jamal Abd. Naser \\ (Dosen Tetap Jurusan Tarbiyah STAIN Pamekasan dan alumni S1 Ummul Quro \\ Makkah Saudi Arabia)
}

\begin{abstract}
Abstrak:
Tulisan ini secara deskriptif argumentatif berusaha mengkaji konsep Islâm tentang kesetaraan gender. Di dalamnya dideskripsikan juga aktualisasi kesetaraan gender dalam perspektif dinamika sosial baik pada level akademis maupun aksi sosial. Tulisan ini akhirnya sampai pada suatu kesimpulan, bahwa konsep feminisme liberal tentang kesetaraan gender lebih equivalen dengan perspektif Islâm, sehingga sampai batas tertentu, ia dapat diterima oleh masyarakat Muslim, melalui pintu masuk kritis-transformatif-adaptif. Lebih dari itu, konsep tersebut berimplikasi teoritis atas beberapa rumusan hukum Islâm, seperti kemungkinan kesetaraan dalam otoritas persaksian dan pola kewarisan antara laki-laki dan perempuan.
\end{abstract}

Kata Kunci:

equalitas gender, feminisme liberal, transformatif adaptif, persaksian, dan kewarisan.

\section{Pendahuluan}

Beberapa dekade belakangan ini, seiring dengan semakin meningkatnya kesadaran bahwa secara substansial manusia adalah setara (egaliter), wacana tentang egalitas menjadi sedemikian dominan, termasuk pula egalitas gender semakin gencar disuarakan, baik oleh kaum laki-laki maupun perempuan. Wacana kesetaraan gender semakin dikembangkan dengan massif, mulai dari level akademis sampai aksi sosial. Tulisan ini hingga batas tertentu, berusaha memotret konsep Islâm tentang hal tersebut, dengan harapan dapat diperoleh pemahaman yang -setidaknya "mendekati" - proporsional, di tengah arus mainstream pemahaman 
yang masih patriarkhal oriented, yang seringkali mendapatkan justifikasi dan legitimasi agama.

\section{Kesetaraan Gender: Suatu Pengertian}

Kesetaraan (equality) merupakan suatu konsep dan atau perilaku yang mencerminkan keseimbangan (equilibriumity), kesejajaran (egality), atau keadilan. Keadilan sendiri bermakna memosisikan sesuatu sesuai dengan posisinya (wad'u syay' fî mahallih). Memosisikan sesuatu pada posisi tersebut acuannya adalah terletak pada norma yang paling substansial dan bukan hanya sekedar didasarkan pada atribut sosial belaka.

Jika keadilan diaplikasikan pada tataran aktifitas kemanusiaan, maka perilaku adil adalah perilaku atau sikap yang memperlakukan manusia sesuai dengan kondisi substansialnya. Sehubungan dengan kondisi substansial manusia, Allâh swt. menegaskan bahwa manusia, secara umum dan tanpa atribut apa pun, termasuk atribut kelamin, adalah makhluk-Nya yang paling mulia. ${ }^{1}$

Satu-satunya atribut kemuliaan yang dilabelkan Allâh swt. kepada khalîfah dan hamba-Nya yang bernama manusia adalah taqwâ, dengan tanpa memandang atribut-atribut apa pun. Salah satu indikator yang paling konkret dari sikap taqwâ tersebut adalah sikap adil, ${ }^{2}$ sehingga kadar ketaqwaan dapat diukur dengan perilaku adil dalam keseharian. Dengan demikian, secara substansial, semua manusia adalah sama dalam arti setara, sehingga tidak dibenarkan untuk merendahkan, melecehkan dan, apalagi, memandang negatif terhadap siapa pun dan jenis kelamin apa pun.

\footnotetext{
1 Lihat al-Qur'ân surat al-Isrâ' (17): 70. Periksa juga Oemar Bakry, Tafsir Rahmat. (Jakarta: Mutiara, 1999), hlm. 553.

2 Menurut ajaran al-Qur'ân, salah satu bagian taqwâ adalah menegakkan keadilan. Allâh berfirman I'dilû huwa aqrabu li al-taqwâ (tegakkanlah keadilan, itulah yang mendekati taqwa). Firman ini diawali dengan pesan agar dalam menegakkan keadilan, kita tidak boleh tergoda oleh rasa benci kepada suatu kelompok manusia (termasuk terhadap perempuan), sehingga menyimpang dari keadilan. Walâ yajri mannakum sana'ânû qawmin 'alâ allâ ta'dilû. (janganlah sampai kebencian terhadap suatu kaum, menyimpangkan kamu dari keadilan). Lihat al-Qur'ân surat al-Mâidah (5): 8). Penjelasan lebih rinci periksa Nurcholish Madjid, Pesan-Pesan Taqwa Nurcholish Madjid: Kumpulan Khutbah Jum'at di Paramadina. (Jakarta: Paramadina, 2000), hlm. 1722.
} 
Namun demikian, secara faktual, pandangan negatif terhadap perempuan misalnya, sesungguhnya telah berlangsung lama dan sangat establish eksistensinya di masyarakat. Di kawasan Timur Tengah, tempat semua agama dan tradisi Semitik diturunkan, sesungguhnya telah terjadi maskulinisasi epistemologis. Citra perempuan di kawasan ini sangat buruk. Beberapa mumi perempuan ditemukan di Mesir menggunakan celana dalam besi dan bersepatu besi yang berat dan berukuran kecil untuk membatasi perjalanan perempuan. Metologi Yunani menggambarkan perempuan sebagai iblis betina (female demon) yang selalu mengumbar nafsu. Tradisi judeo-christianity memojokkan perempuan sebagai penyebab dosa warisan dalam drama kosmik. Peradaban Sasania Zoroaster menyembunyikan perempuan menstruasi di goa-goa gelap yang jauh dari perkampungan dan peradaban Hindu yang memerabukan (membakar hidup-hidup) para isteri di samping suaminya yang meninggal. ${ }^{3}$

Pandangan-pandangan demikian, jelas sangat tidak direstui dalam agama Islâm. Karena itu, pandangan hidup yang memandang negatif terhadap status siapa pun, perempuan misalnya, semapan dan sekokoh apa pun, meski didasarkan pada "interpretasi doktrin" keagamaan, demi keadilan dan kesetaraan, harus diluruskan, sebab jika tidak demikian, justru akan melahirkan beberapa tatanan sosial yang tidak adil, ${ }^{4}$ sesuatu yang sesungguhnya sangat tidak dikehendaki dan sangat dibenci oleh Tuhan.

Adapun istilah gender berbeda dengan istilah seks. Ann Oakley adalah orang yang mula-mula membedakan dua istilah tersebut. ${ }^{5}$ Gender merujuk kepada perbedaan karakter laki-laki dan perempuan berdasarkan konstruksi sosial budaya, yang berkaitan

\footnotetext{
3 Periksa Nasaruddin Umar, “ Kajian Kritis terhadap Ayat-Ayat Gender (Pendekatan Hermeneutik)", dalam Lathiful Khuluq (ed.) Rekonstruksi Metodologis Wacana Kesetaraan Gender dalam Islam. (Yogyakarta: PSW UIN Sunan Kalijaga-ICIHEP-Pustaka Pelajar, 2002), hlm. 107-108.

${ }_{4}^{4}$ Dalam konteks relasi gender, ketidakadilan tersebut termanifestasi dalam beberapa bentuk seperti stereotyping, subordinasi, marginalisasi, beban ganda, dan kekerasan. Periksa Mansour Faqih, Analisis Gender dan Transformasi Sosial. (Yogyakarta: Pustaka pelajar, 1996).

5 Susilaningsih dan Agus M. Najib, Kesetaraan Gender di Perguruan Tinggi Islam. (Yogyakarta: PSW UIN-Mc Gill IISEP, 2004), hlm. 11.
} 
dengan sifat, status, posisi, dan perannya dalam masyarakat ${ }^{6}$. Sedangkan istilah seks merujuk kepada perbedaan jenis kelamin lakilaki dan perempuan secara biologis terutama yang berkaitan dengan prokreasi dan reproduksi. Laki-laki dicirikan dengan adanya sperma dan penis, perempuan dicirikan dengan adanya sel telur, rahim, vagina dan payudara. Ciri jenis kelamin secara biologis ini bersifat bawaan, permanent, dan tidak dapat dipertukarkan.

Perbedaan gender, disebut juga perbedaan jenis kelamin secara sosial budaya, terkait dengan perbedaan secara seksual karena dia merupakan produk dari pemaknaan masyarakat pada sosial budaya tertentu tentang sifat, status, posisi, peran laki-laki dan perempuan dengan ciri-ciri biologisnya. Laki-laki sebagai pemilik sperma dianggap mempunyai sifat kuat dan tegas, menjadi pelindung, bertugas menjadi pencari nafkah dan menjadi pemilik dunia kerja (publik) dan sebagai orang pertama. Perempuan sebagai pemilik sel telur dan rahim dan kemampuan melahirkan dianggap bersifat lemah-lembut, perlu dilindungi, mendapat pembagian sebagai pengasuh anak, dan tugas domestik serta dianggap sebagai orang nomor dua. ${ }^{7}$

Karena sifat dan peran gender merupakan produk dari konstruk sosial budaya, maka ia bersifat tidak permanen dan dapat dipertukarkan, sehingga jika perbedaan gender menghasilkan berbagai bentuk ketidakadilan dan penindasan terhadap warga masyarakat dengan jenis kelamin tertentu, ${ }^{8}$ biasanya perempuan, maka perbedaan gender tersebut mesti dikikis melalui

6 Periksa Nasaruddin Umar, Argumen Kesetaraan Gender: Perspektif al-Qur'ân. (Jakarta: Paramadina, 2001), hlm. 35. Dalam konteks ini, Linda L. Lindsey menyatakan bahwa ketetapan masyarakat perihal penentuan seseorang sebagai laki-laki atau perempuan adalah termasuk bidang kajian gender. Periksa Linda L. Lindsey, Gender Roles: a Sosiological perspective. (New Jersey: Prentice Hall, 1990), hlm. 2.

7 Faqih, Analisis Gender, hlm. 7-8.

8 Pada kenyataannya perbedaan gender telah melahirkan berbagai ketidakadilan, bukan saja kepada perempuan tetapi juga kepada laki-laki. Laki-laki yang mendapat peran sebagai pencari nafkah dan pelindung dituntut oleh budaya untuk menjadi perkasa, mampu kerja keras dan bersifat rasional sehingga kehilangan sisi kelembutan dan sikap damai yang merupakan kebutuhan lain dalam kehidupan manusia. Sebaliknya perempuan yang mendapat peran sebagai penanggungjawab pekerjaan domestik dianggap bersifat lemah dan pasif, maka tidak mampu untuk berkiprah di dunia publik. 
pengarusutamaan wacana kesetaraan gender (al-musâwâa aljinsiyah/gender equality).

Dari bahasan di atas, dapat disimpulkan bahwa kesetaraan gender adalah suatu konsep atau perilaku yang memandang laki-laki dan perempuan sebagai sesama makhluk Tuhan dengan status yang sejajar, equal, tanpa steriotyping, subordinasi, dan dominasi serta saling melengkapi dan saling membutuhkan, dengan tetap memperhatikan kodratnya secara seksual. ${ }^{9}$

\section{Equalitas Gender dalam Dinamika Sosial}

Seiring dengan semakin kuatnya kesadaran tentang relasi gender, maka wacana kesetaraan gender mengalami massifitas, mulai dari level akademis sampai pada aksi sosial. Pada level akademis, mulai dikembangkan kajian-kajian tentang kesetaraan gender baik melalui pendekatan historis maupun dekonstruksi metodologis terhadap tafsiran teks-teks keagamaan ${ }^{10}$. Sedangkan pada level praksis, antara lain, dilakukan melalui aksi sosial dan penyadaran terhadap kaum perempuan atas dasar paradigma teoritis tertentu mulai dari yang tradisional ${ }^{11}$ sampai yang modern ${ }^{12}$ bahkan ultramodern seperti yang dipelopori oleh para feminis radikal.

${ }_{9}$ Artinya, laki-laki tidak mesti di sektor publik dan perempuan tidak mesti di sektor domestik, sehingga tidaklah dipandang sebagai aib bagi seorang perempuan melakukan pekerjaan di sektor publik seperti mengurus partai, bekerja kasar, atau pun lainnya demi memperoleh penghasilan dan atas dasar itu pula tidak dapat dinilai, kecuali terpuji, seorang laki-laki (atau lebih khusus suami) yang membantu isterinya dalam urusan rumah tangga. Lebih detail Periksa M. Quraish Shihab, "Kesetaraan Gender dalam Islam", dalam Umar, Argumen Kesetaraan Gender, hlm. xxxvii

10 Untuk kasus ini, banyak karya-karya intelektual yang berbasis agama yang menggugat terhadap karya-karya misoginis, seperti karya Musdah Mulia, Perempuan Pembaru Agama, Nasaruddin Umar, Argumen Kesetaraan Gender: Perspektif al-Qur'ân; Husien Muhammad, Figh Perempuan: Refleksi Kiai Atas Wacana Agama dan Gender;

${ }^{11}$ Misalnya melalui strategi Women in Development (WID) dan Gender and Development $(G A D)$. Strategi WID adalah suatu strategi untuk meningkatkan perempuan dalam pembangunan melalui program yang memfokuskan pada pemberdayaan perempuan. Asumsinya adalah ketimpangan gender terjadi karena rendahnya kualitas sumber daya perempuan sebab selama ini tidak memperoleh perhatian dan kesempatan yang sama dengan laki-laki dalam program pembangunan. Bentuknya antara lain adalah melalui PKK, Dharma Wanita, dan sejenisnya. Sedangkan strategi GAD adalah mempromosikan usaha mengintegrasikan gender dalam pembangunan. Asumsinya adalah ketertinggalan perempuan disebabkan oleh adanya sikap 
Pada gilirannya, perspektif yang digunakan para tokoh feminisme dalam melihat ketimpangan relasi gender dalam masyarakat sehingga melahirkan stereotiping, subordinasi, marginalisasi, beban ganda, dan kekerasan ${ }^{13}$ telah mewujudkan beragam pola gerakan feminisme, yang untuk mudahnya, diklasifikasikan secara trikotomik ke dalam tiga gerakan, yaitu (1) gerakan feminisme liberal, (2) gerakan feminisme marxis-sosialis, dan (3) feminisme radikal. ${ }^{14}$

Dalam perspektif kaum feminis liberal, semua manusia, laki dan perempuan, diciptakan seimbang dan serasi, karena itu, mestinya, tidak terjadi penindasan antara satu dengan lainnya. Feminisme liberal diinspirasi oleh prinsip pencerahan bahwa lakilaki dan perempuan sama-sama mempunyai ciri khas, namun secara ontologi keduanya sama, hak-hak laki-laki, dengan sendirinya, juga menjadi hak perempuan. Meski demikian, kelompok ini tetap

masyarakat yang tidak adil terhadap laki-laki dan perempuan yang kemudian berpengaruh pada bentuk dari sistem, struktur ideologi, dan budaya dari masyarakat tersebut sehingga melahirkan pola relasi gender yang tidak adil. Wujud strategi ini adalah kegiatan-kegiatan pelatihan sensitivitas gender dalam proyek pembangunan. Periksa Mansour Faqih, "Gender Mainstreaming Strategi Mutakhir Gerakan perempuan", dalam Mandy Mcdonald, et.al., Gender dan Perubahan Organisasi Menjembatani Kesenjangan Antara Kebijakan dan Praksis, terj. Omi Intan Naomi, (Yogyakarta: INSIST, 1999).

12 Strategi moderen adalah dikenal dengan istilah Gender Mainstreaming (GM) atau pengarusutamaan gender dengan asumsi bahwa ketimpangan gender disebabkan adanya sistem dan struktur masyarakat yang tidak berkeadilan gender. Strategi ini adalah modifikasi dari strategi GAD dengan melengkapinya melalui usaha intervensi secara cepat terhadap terjadinya perubahan pada sistem dan struktur suatu organisasi, melalui perubahan dasar filosofis, rumusan kebijakan, pola pembagian kerja, dan pola interaksi sosialnya. Periksa Fakih, "Gender Mainstreaming".

13 Stereotyping adalah pemberian label sehingga perempuan mendapat citra negatif, misalnya perempuan lemah, emosional, dan hanya bertugas sebagai ibu rumah tangga. Subordinasi perempuan adalah diskriminasi terhadap perempuan dalam bidang kekuasaan dan pengambilan keputusan, karena perempuan memperoleh label nomor dua maka ia berada di bawah dominasi laki-laki dan haknya untuk memperoleh posisi tawar kepemimpinan sering kali tidak diakui. Marginalisasi perempuan muncul dari sikap tidak menganggap penting atas eksistensi perempuan sehingga aksesnya terhadap pendidikan dan sumber ekonomi dinomorduakan. Beban ganda terjadi ketika pekerjaan domestik hanya merupakan tugas perempuan, sehingga bagi mereka yang bekerja di sektor publik ketika sampai di rumah wajib menyelesaikan tugas domestiknya.

${ }^{14}$ Umar, Argumen Kesetaraan, hlm. 64-68. 
menolak persamaan secara menyeluruh antara laki-laki dan perempuan. Dalam beberapa hal, terutama yang berkaitan dengan fungsi reproduksi, ia masih tetap memandang perlu adanya pembedaan (distinction), sebab bagaimana pun juga, fungsi organ reproduksi bagi perempuan membawa konsekuensi logis dalam kehidupan di masyarakat.

Dengan perspektif demikian, kelompok ini membenarkan perempuan bekerja bersama-sama dengan laki-laki, bahkan menghendaki agar perempuan diintegrasikan dalam semua peran, termasuk pada sektor publik, sehingga tidak ada lagi kelompok yang lebih dominan. Organ reproduksi bukan merupakan penghalang terhadap peran-peran tersebut.

Sedangkan feminisme Marxis-sosialis hampir sama dengan feminisme liberal, tetapi lebih kental dengan muatan ideologi Marxissosialisnya. Karenanya, untuk mengubah posisi inferior perempuan, mesti diadakan perubahan struktural secara menyeluruh, bahkan, bila perlu, dengan menggunakan kekerasan. ${ }^{15}$

Adapun feminisme radikal berusaha menggugat semua lembaga yang dianggap merugikan perempuan, bahkan, lebih jauh, menuntut persamaan seks dalam arti kepuasan seksual juga bisa diperoleh dari sesama perempuan sehingga mentoleransi praktik lesbian. Dalam pandangannya, perempuan tidak harus bergantung kepada laki-laki, bukan saja dalam hal pemenuhan kepuasan kebendaan tetapi juga pemenuhan kebutuhan seksual. Laki-laki, dalam pandangan mazhab ini, adalah masalah bagi perempuan, lakilaki selalu mengeksploitasi fungsi respreduksi perempuan dengan berbagai dalih. Pendek kata, feminisme radikal berusaha mewujudkan secara ideologis dan aktual persamaan secara total antara perempuan dengan laki-laki ${ }^{16}$

15 Sementara kaum feminis liberal, dalam memperjuangkan aspirasinya, memandang bahwa perubahan struktur sosial secara menyeluruh bukan merupakan suatu kemestian, tetapi cukup melibatkan perempuan dalam berbagai peran seperti dalam peran sosial, ekonomi, dan politik. Periksa Umar, Argumen Kesetaraan, hlm. 65.

16 Pandangan kelompok ini mendapatkan tantangan keras dan luas dari kalangan feminisme yang lain. Tokoh feminisme liberal yang banyak berpikit realistis tidak sepenuhnya setuju dengan pendapat ini. Persamaan secara total pada akhirnya akan merepotkan dan merugikan perempuan sendiri. Laki-laki yang tanpa beban organ reproduksi secara umum akan sulit diimbangi oleh perempuan. 
Demikianlah, kecenderungan aspirasi feminisme dalam dinamika kehidupan sosial kontemporer. Dalam konteks ini, masyarakat Islâm, jelas tidak akan mentoleransi gerakan feminisme Marxis-sosialis secara ideologis karena keberatan dengan nilai kekerasan yang diusahakannya. Demikian juga terhadap feminisme radikal, yang jelas-jelas irasional dan bertentangan dengan kaidah Islâm dan akal sehat. Feminisme yang, barangkali, dapat ditoleransi adalah feminisme liberal yang realistis, karena memang sampai batas tertentu, memiliki kesesuaian dengan nilai-nilai Islâm. Dalam konteks demikian, sangat urgen untuk dikaji perspektif Islâm tentang kesetaraan gender.

\section{Equalitas Gender dalam Islâm dan Implikasinya atas Beberapa Rumusan Hukum Islâm}

Untuk mengkaji bagaimana sikap Islâm terhadap kesetaraan gender, dapat dilalui dari perspektif prinsip-prinsip al-Qur'ân, sebagai sumber ajaran asasi Islâm, tentang kesetaraan gender dan implikasi praktisnya dalam bberapa rumusan hukum Islam serta perspektif historis sikap Nabî Muhammad terhadap kesetaraan gender.

Sehubungan dengan prinsip al-Qur'ân tentang kesetaraan gender, Nasaruddin Umar menyebutkan lima prinsip, yakni (1) lakilaki dan perempuan sama-sama sebagai hamba, (2) laki-laki dan perempuan sama-sama sebagai khalîfah, (3) laki-laki dan perempuan menerima perjanjian primordial, (4) Adam dan Hawa, terlibat secara aktif dalam drama kosmis, dan (5) laki-laki dan perempuan berpotensi meraih prestasi. ${ }^{17}$

Dalam kapasitas manusia sebagai hamba, tidak ada perbedaan antara laki-laki dan perempuan, karena masing-masing akan mendapatkan penghargaan dari Tuhan sesuai dengan kadar pengabdiannya. ${ }^{18}$ Keduanya mempunyai potensi dan peluang yang sama untuk menjadi hamba ideal. ${ }^{19}$ Kekhususan yang diperuntukkan

17 Umar, Argumen Kesetaraan Gender, hlm. 247-268.

18 Lihat al-Qur'ân surat al-Nahl (16): 87.

19 Hamba ideal dalam al-Qur'ân biasa diistilahkan dengan orang-orang yang bertaqwa (muttaqûn). Untuk mencapai derajat muttaqûn ini tidak dikenal adanya perbedaan jenis kelamin, suku bangsa, atau kelompok etnis tertentu. Lihat surat alHujurat (49): 13. 
kepada laki-laki seperti suami lebih tinggi di atas isteri, laki-laki pelindung perempuan, laki-laki memperoleh warisan lebih banyak, dan diperkenankannya laki-laki berpoligami, tidak serta merta menyebabkan laki-laki menjadi hamba-hamba utama. Kelebihankelebihan tersebut diberikan kepada laki-laki dalam kapasitasnya sebagai anggota masyarakat yang memiliki peran publik dan sosial "lebih" ketika ayat-ayat al-Qur'ân tersebut diturunkan.

Demikian pula, dalam posisinya sebagai khalîfah, al-Qur'ân tidak menunjuk kepada salah satu jenis kelamin atau kelompok etnis tertentu ${ }^{20}$. Laki-laki dan perempuan mempunyai fungsi yang sama sebagai khalîfah, yang akan mempertanggungjawabkan tugas kekhalifahannya di bumi sebagaimana halnya mereka harus bertanggung jawab sebagai hamba Tuhan.

Laki-laki dan perempuan pun sama-sama mengemban amanah dan menerima perjanjian primordial dengan Tuhan. ${ }^{21}$ Dalam alQur'ân tidak ditemukan satu ayat pun yang menunjukkan keutamaan seseorang karena faktor jenis kelamin atau karena keturunan suku bangsa tertentu. Kemandirian dan otonomi perempuan dalam tradisi Islâm sejak awal begitu kuat. ${ }^{22}$

Perspektif negatif tentang perempuan, acapkali didasarkan pada cerita Kitab Suci agama Yahudi (Tawrat) tentang drama kosmis, yakni cerita tentang dikeluarkannya Adam dan pasangannya, ${ }^{23}$ Hawa (Eva),

20 Periksa al-Qur'ân surat al-Baqarah (2): 30 dan surat al-An'âm (6): 165.

${ }^{21}$ Lihat al-Qur'ân surat al-A'râf (7): 172.

22 Buktinya, perjanjian bay'ah, sumpah, dan nadzar yang dilakukan oleh perempuan mengikat dengan sendirinya sebagaimana halnya laki-laki. Periksa al-Qur'ân surat alMâ'idah (5): 89 dan surat al-Mumtahanah (60): 12. Dalam tradisi Yahudi-Kristen, seorang perempuan hidup di dalam pangkuan ayah, maka perjanjian, sumpah dan nadzar-nya dapat digugurkan oleh ayah yang bersangkutan. Jika seorang perempuan hidup dalam pangkuan suaminya, maka perjanjian, sumpah, dan nadzar-nya dapat digugurkan oleh suaminya. Sebagai contoh dalam Kitab Bilangan (30): 5 dinyatakan: "Tetapi jika ayahnya melarang dia (anak perempuan) pada waktu mendengar itu (nazar dan janji perempuankepada Tuhan) maka segala nazar dan janji yang mengikat diri anaknya itu tidak akan berlaku, dan Tuhan akan mengampuni perempuan itu, sebab ayahnya telah melarangnya".

23 Terdapat informasi menarik dalam literatur Yahudi, bahwa Hawa bukan saja ciptaan kedua, tetapi juga pasangan kedua. Pasangan pertama Adam ialah Lillith, yang digambarkan sebagai setan betina (female demon) yang berwajah manusia, berambut panjang, mempunyai sayap, berkeliaran di malam hari. Ia diciptakan dari tanah bersama-sama dengan Adam dalam waktu bersamaan. Tetapi karena Lillith 
dari Surga sampai ke bumi, yang mana Hawa dianggap sebagai penyebab utama. ${ }^{24}$ Berbeda dengan itu, dalam al-Qur'ân, semua ayat yang menceritakan tentang drama kosmis, selalu menekankan kedua belah pihak secara aktif dengan menggunakan kata ganti untuk dua orang (humâ), yakni kata ganti untuk Adam dan Hawa, ${ }^{25}$ bahkan alQur'ân dengan tegas menyatakan bahwa peluang untuk meraih prestasi maksimum tidak ada perbedaan antara laki-laki dan perempuan ${ }^{26}$ sehingga dapat ditegaskan bahwa al-Qur'ân sesungguhnya mengisyaratkan keseteraan gender yang ideal dan memberikan ketegasan bahwa prestasi individual, baik dalam bidang spiritual maupun karier profesional, tidak mesti dimonopoli oleh salah satu jenis kelamin tertentu ${ }^{27}$. Demikianlah, secara ideal Islâm sedemikian eksesif dalam mewujudkan kesetaraan gender.

tidak mau menjadi pelayan Adam, ia meninggalkan Adam dan selanjutnya bersamasama Iblis menjadi pengganggu manusia. Tuhan lalu menciptakan pasangan kedua (Hawa) dari tulang rusuk Adam sebagai pelayan baru (the new helper). Makhluk misterius ini dikaitkan dengan salah satu pasal dalam Kitab Perjanjian Lama (Yesaya (34): 14). Periksa Umar, Argumen Kesetaraan, hlm. 231. Dalam al-Qur'ân dan literatur Islâm, nama Lillith tidak dikenal. Dalam Hadits pun hanya dikenal nama Hawa sebagai pasangan Adam.

24 Sebagaimana disebut dalam Kitab Kejadian 3: 12: Manusia itu menjawab: "Perempuan yang Kau tempatkan di sisiku, dialah yang memberi dari buah pohon itu kepadaku, maka kumakan".

25 Seperti dinyatakan dalam al-Qur'ân surat al-Baqarah (2): 35 bahwa keduanya diciptakan di surga dan memanfaatkan fasilitas surga berdua; keduanya mendapat kualitas godaan yang sama dari setan sebagaimana dinyatakan dalam al-Qur'ân surat al-A'râf (7): 20; sama-sama memakan buah khuldi dan bersama menerima akibat jatuh ke bumi (QS. al-A'râf (7): 22); setelah jatuh ke bumi, keduanya sama-sama memohon ampun kepada Tuhan (QS. al-A'râf (7): 23) dan kemudian keduanya mengembangkan keturunan, saling melengkapi dan saling membutuhkan (QS. alBaqarah (2): 187). Uraian lebih rinci, periksa Masdar F. Mas'udi, Islam dan Hak-Hak Reproduksi Perempuan: Dialog Fiqh pemberdayaan. (Bandung: Mizan, 1997), hlm. 43-45.

26 Periksa al-Qur'ân surat al-Imrân (3): 195; al-Nisâ' (4): 124; al-Nahl (16): 97; Ghafir (40):40. Al-Qur'ân dengan tegas menyatakan bahwa perempuan adalah mitra lakilaki, sehingga hubungan mereka adalah setara, dan tidak ada yang lebih istemawa, tetapi saling melengkapi dan saling membutuhkan. Periksa al-Qur'ân surat alBaqarah (2): 187 dan al-Tawbah (9): 71.

27 Dalam hubungan ini, Komaruddin Hidayat menyatakan bahwa citra perempuan yang diidealkan al-Qur'ân adalah perempuan yang memiliki kemandirian politik (alistiqlal al-siyâsah) (QS al-Mumtahanah (60): 12) sebagaimana sosok Ratu Balqis perempuan penguasa yang mempunyai kerajaan super power lahâ 'arsyun 'azhîm (QS. al-Naml (27): 23); memiliki kemandirian ekonomi (al-Istiqlal al-Iqtishadi) (QS. Al-Nahl 
Kemudian, perspektif historis perilaku Nabî Muhammad saw. terhadap kesetaraan gender adalah bahwa pada realitasnya Nabi Muhammad mendemonstrasikan persamaan kedudukan laki-laki dan perempuan dalam aktifitas sosial, mulai dari bidang kewirausahaan, politik sampai pada peperangan. ${ }^{28}$ Fenomena ini diakui oleh David S. Powers, bahwa pada masa-masa awal Islâm (the proto Islamic law) kebebasan perempuan dalam berbagai bidang sangat nampak. ${ }^{29}$ Pengakuan senada juga diakui oleh Wiebke Walther. ${ }^{30}$

Ketika Nabi wafat, semangat kesetaraan gender yang diusung Rasûlullâh, berangsur-angsur hilang dan tidak dilanjutkan oleh para penguasa Islâm selanjutnya. Buktinya, setelah Abû Sufyan, pendiri dawlah Banî Umayah, mengambil alih kekuasaan dan memindahkan pusat kekuasaan politik Islâm ke Damaskus, yang terkenal sebagai basis Yahudi dan Kristen dengan segala bias gendernya, banyak

(16):97) seperti pemandangan yang disaksikan Nabi Musa di Madyan, perempuan pengelola peternakan (QS. Qashash (28): 23); memiliki kemandirian dalam menentukan pilihan pribadi (al-istiqlal al-syakhsyî) yang diyakini kebenarannya sungguhpun harus menghadapi suami bagi perempuan yang sudah berkeluarga (QS. al-Tahrîm (66): 11) atau menentang opini publik bagi perempuan yang belum berkeluarga (QS. al-Tahrim/66: 12). Perempuan dibenarkan untuk menyuarakan kebenaran dan melakukan oposisi terhadap kebobrokan (QS. al-Tawbah (9): 71), bahkan al-Qur'ân menyerukan perang terhadap suatu negeri yang menindas kaum perempuan (QS. al-Nisâ'(4): 5), karena laki-laki dan perempuan sama-sama berpotensi sebagai kahlifah dan sama-sama sebagai hamba. Periksa Komaruddin Hidayat, "Pengantar Penerbit", dalam Umar, Argumen Kesetaraan, hlm. xxvi.

28 Nasaruddin Umar, "Metode Penelitian Berperspektif Gender tentang Literatur Islam", dalam Lathiful Khuluq, Peny. Rekonstruksi Metodologis Wacana Kesetaraan Gender dalam Islam. (Yogyakarta: PSW UIN Sunan Kalijaga ICIHEP Pustaka pelajar, 2002), hlm. 103. Fakta sejarah menunjukkan bahwa pada generasi sahabat terdapat 1232 sahabat perempuan yang beraktifitas di dunia ilmu. Periksa Mas'udi, Islam dan Hak-Hak, hlm. 57. Pada masa Nabî Muhammad dan sahabatnya, banyak perempuan/isteri yang bekerja. Ada yang bekerja sebagai perias pengantin, seperti Ummu Satim binti Malhan, Shafiyah binti Huyay. Istri nabi yang lain, Zaynab binti Jahsyi aktif bekerja sebagai penyamak kulit binatang, dan Raythah, istri Abd Allâh bin Mas'ûd sangat aktif bekerja karena ekonomi keluarganya tidak mencukupi. Periksa Shihab, "Kesetaraan Gender", dalam Umar, Argumen Kesetaraan, h. xxxv. Bandingkan dengan Husien Muhammad, Figh Perempuan: Refleksi Kiai Atas Wacana Agama dan Gender. (Yogyakarta: LkiS, 2002), hlm. 137-145.

29 Periksa David S. Powers, Peralihan Kekayaan dan Politik Kekuasaan: Kritik Historis Hukum Waris. Ter. Arif Maftuhin, (Yogyakarta: LKiS, 2001).

30 Wiebke Walther, Women in Islam; From Medieval to Modern Times. (New York: Markus Wiener Publishing, 1993) 
mengintroduksi norma-norma lokal kota bekas jajahan RomawiBizantium ${ }^{31}$. Demikian pula, setelah rezim Banî Abbâsiyah merebut kekuasaan dan memindahkan ibu kota ke Baghdad yang bertetangga dengan pusat kekuasaan Persia, dengan tradisi missoginis Sasanid Persia, mengintroduksi pandangan stereotype terhadap perempuan seperti yang banyak terlihat dalam banyak kitab figh yang disusun di kota tersebut. ${ }^{32}$

Dengan kultur kekuasaan yang mentoleransi budaya setempat itulah, pada akhirnya membangkitkan kembali "alam bawah sadar" epistemologi maskulin yang sudah berlangsung lama di kawasan Timur Tengah ${ }^{33}$ sehingga terjadi pandangan bias gender, yang pada gilirannya apa yang diintroduksi oleh Nabî Muhammad menjadi terpendam dan terhegemoni oleh tradisi besar tersebut, bahkan ajaran dan peninggalan Nabi tersebut ditafsirkan dalam bingkai diskriminasi gender, ${ }^{34}$ yang seolah-olah di-nisbah-kan pada ajaran Islâm ideal, pada hal sesungguhnya interpretasi terhadapnya, sangat boleh jadi, "melenceng" dari elan profetis Islâm sebagai rahmatan li al- 'âlamîn.

Berdasarkan deskripsi dan analisis historis di atas, kiranya dapat dipahami bahwa steriotyping dan berbagai perlakuan timpang

31 Misalnya tradisi harem (gundik) kembali menjadi aktual di kalangan bangsawan dan penguasa Banî Umayyah.

32 Umar, Metode Penelitian, hlm. 105.

33 Maskulinisasi epistemologi sudah berlangsung lama di kawasan Timur Tengah jauh sebelum al-Qur'ân diturunkan, dunia epistemologi sudah dipengaruhi kosmologi, mitologi, dan peradaban kuno yang cenderung misoginis di kawasan ini seperti kosmologi Mesir kuno di selatan, mitologi Yunani kuno di Barat, tradisi Yahudi-kristen di sepanjang Laut Merah, peradaban Sasania-Zoroaster di Timur yang berpusat di Ktesipon, Mesopotamia. Umar,"Kajian Kritis terhadap Ayat", hlm. 107.

34 Seperti yang telah ditunjukkan Nasaruddin Umar dalam disertasinya yang menyebutkan paling tidak terdapat 10 pintu bias gender dalam penafsiran teks alQur'ân, yaitu (1) pembakuan tanda huruf, tanda baca dan qira'at, (2) pengertian kosa kata (mufradat), (3) penetapan rujukan kata ganti (dhamir), (4) penetapan batas pengecualian (istisna), (5) Penetapan arti huruf 'athaf (6) bias dalam struktur bahasa, (7) bias dalam kamus bahasa Arab, (8) bias dalam metode tafsir, (9) pengaruh riwayat israilliyat, dan (10) bias dalam pembukuan dan pembakuan kitab-kitab fiqh. Penjelasan elaboratif tentang hal tersebut periksa Nasaruddin Umar, Argumen Kesetaraan Gender, hlm. 268-299. Dalam karyanya yang lain, di samping 10 pintu tersebut, masih terdapat dua pintu lagi yakni, (1) bias dalam pembukuan kitab hadits dan (2) bias yang didasarkan pada mitos. Periksa Umar, "Metode Penelitian", hlm. 99-102. 
yang selama ini didemonstrasikan oleh generasi Islâm pasca kehidupan Nabî Muhammad saw. sesungguhnya bukan merupakan ajaran murni Islâm. Praktik demikian, tidak lebih dari sekedar konstruksi budaya yang tidak perlu disakralkan. Karenanya, ia mesti didekonstruksi, sehingga praktik-praktik marginalisasi perempuan dalam segala sektor kehidupan dapat dihilangkan karena sesungguhnya ia merupakan pelanggaran dari Islâm. Implikasinya, perempuan dapat menentukan nasibnya sendiri, dalam segala hal, dengan tanpa adanya intervensi dan pemaksaan kalangan laki-laki dalam bentuk apa pun. ${ }^{35}$

Dalam konteks inilah, diperlukan pola pemahaman yang tepat terhadap teks-teks agama Islâm, yang dalam tampak eksternalnya sepertinya memarginalisasi perempuan, sehingga terwujud suasana pergaulan kemanusiaan yang Islâmi, dalam makna hakikinya. Pola pemahaman yang tepat, dalam konteks ini dapat dicapai melalui mempelajari asbâb al-nuẑ̂ul atau asbâb al-wurud (historical setting) sebuah teks keagamaan, sehingga, dalam konteks hukum Islâm, dapat dicapai hikmat wa asrâr al-tasyrî́ yang implikasinya tidak ada lain adalah terwujudnya keadilan dan kesetaraan dalam segala dimensinya.

Salah satu wujud dari keadilan dan kesetaraan jender dalam hukum Islâm adalah kesetaraan dalam otoritas persaksian. AlQur'ân ${ }^{36}$ memang telah menyatakan bahwa kesaksian seorang lakilaki sama dengan kesaksian dua orang perempuan. Namun, laki-laki memperoleh otoritas persaksian satu berbanding dua dengan perempuan karena ketika itu fungsi dan peran publik berada di pundak laki-laki. Kekurangan "akal" dan "agama" (naqisat al-'aql wa al-dîn), sebagaimana dinyatakan dalam Hadîts sehingga banyak kaum perempuan masuk neraka, tidak boleh dipahami Islâm telah mendiskreditkan perempuan. Kata kekurangan akal dalam $\underline{\text { Hadits }}$

\footnotetext{
35 Sudah tentu pernyataan ini jangan dipahami bahwa kalangan perempuan bebas sebebas-bebasnya dalam menentukan segala aktivitasnya. Dalam konteks ini, lakilaki hendaknya dijadikan mitra, dalam makna dimintai pertimbangan dan sarannya. Para istri sudah selayaknya bermusyawarah dengan suami dalam menentukan apa yang dapat dilakukan istri ketika ia mesti bekerja di luar rumah (sektor publik) dan suami mesti memberikan advis dan saran yang tepat serta proporsional sekaligus tidak asal melarang atas dasar ajaran agama.

${ }^{36}$ Lihat al-Qur'ân surat al-Baqarah (2): 282.
} 
tersebut tidak berarti perempuan secara potensial tidak mampu menyamai dan melampaui prestasi kreatifitas akal dan ibadah lakilaki. Demikian pula kekurangan agama tidak bisa dilekatkan kepada perempuan. Kekurangan agama, kalau lah boleh disebut demikian, terjadi pada diri perempuan karena memang hanya perempuan lah yang menjalani masa menstruasi. Laki-laki tidak menjalani siklus menstruasi sehingga ia tidak boleh meninggalkan ibadah-ibadah wajib tanpa alasan lain yang dapat dibenarkan. Peniadaan sejumlah ibadah dalam masa menstruasi adalah dispensasi khusus bagi perempuan dari Tuhan. Mereka tidak dikenakan akibat apa pun dari Tuhan karena menjalani proses menstruasi. Kekurangan akal (nuqsan al-'aql) masih dapat dipertanyakan lebih lanjut apa yang sesungguhnya dimaksud kata al-'aql pada masa Nabi. Jika kekurangan akal dikaitkan dengan kualitas persaksian, sementara persaksian berhubungan dengan faktor budaya, maka bisa saja dipahami maksud kekurangan akal tersebut adalah keterbatasan penggunaan fungsi bagi perempuan karena adanya pembatasanpembatasan budaya, sehingga sifatnya bukan permanen atau alamiah.

Hal lain yang juga dinilai sebagai diskriminasi berdasarkan gender dalam hukum Islâm adalah pola kewarisan. Seorang perempuan muslimah menerima setengah dari bagian pria muslim ketika keduanya berada dalam tingkatan yang sama dalam hubungannya dengan orang yang meninggal. ${ }^{37}$ Pengabsahan alQur'ân atas tersebut lebih didasarkan pada kondisi keamanan dan tingkat sosial ekonomi kaum perempuan. Ini berarti kewarisan alQur'ân bersifat historis dan konstektual. Karenanya, berkenaan dengan hal itu, Masdar F. Mas'udi dengan tegas menyatakan bahwa jika ternyata latar belakang sosial ekonomi dalam keluarga sudah berubah, tidak ada halangan sedikit pun untuk melakukan modifikasi terhadap sistem kewarisan (2:1) itu sendiri. Yang penting ajaran prinsip $\left(q^{a t h}{ }^{\prime} \hat{\imath}\right)$ dalam Islam tentang kemitraan dan keadilan tetap ditegakan. ${ }^{38}$

\section{Penutup}

\footnotetext{
37 Al-Qur'ân surat al-Nisâ' (4): 11.

${ }^{38}$ Mas' udi, Islam, hlm. 54.
} 
Berdasarkan deskripsi di atas, kiranya dapat dihipotesiskan bahwa feminisme yang dapat ditoleransi oleh Islâm adalah feminisme liberal, karena memang sampai batas tertentu, memiliki kesesuaian dengan nilai-nilai Islâm. Atas dasar itu, pengarusutamaan gender (gender mainstreaming) dalam dinamika masyarakat Muslim dewasa ini dapat dilakukan melalui "pintu masuk" feminisme liberal, yang sudah tentu bukan secara transmitif akan tetapi secara transformatif adaptif39 terhadap doktrin dan nilai ideal Islâm (al-Qur'ân). Melalui model ini pula, sudah saatnya untuk difikirkan tentang kemungkinan kesetaraan dan keadilan, misalnya, dalam otoritas persaksian dan pola kewarisan antara laki-laki dan perempuan. Wallâh a'lam bi alShawab.

\section{Daftar Pustaka}

Bakry, Oemar. Tafsir Rahmat. Jakarta: Mutiara, 1999.

Faqih, Mansour. Analisis Gender dan Transformasi Sosial. Yogyakarta: Pustaka Pelajar, 1996.

--------. "Gender Mainstreaming Strategi Mutakhir Gerakan perempuan, dalam Mandy Mcdonald, et.al., Gender dan Perubahan Organisasi Menjembatani Kesenjangan Antara Kebijakan dan Praksis. Ter. Omi Intan Naomi. Yogyakarta: INSIST, 1999.

Lindsey, Linda L. Gender Roles: a Sosiological perspective. New Jersey: Prentice Hall, 1990.

Madjid, Nurcholish. Pesan-Pesan Taqwa Nurcholish Madjid: Kumpulan Khutbah Jum'at di Paramadina. Jakarta: Paramadina, 2000.

Mas'udi, Masdar F. Islam dan Hak-Hak Reproduksi Perempuan: Dialog Figh pemberdayaan. Bandung: Mizan, 1997.

Muhammad, Husien. Figh Perempuan: Refleksi Kiai Atas Wacana Agama dan Gender. Yogyakarta: LkiS, 2002.

39 Konsep transmitif berbeda dengan konsep transformatif adaptif. Yang pertama, mengambil sesuatu secara total tanpa adaptasi dengan struktur budaya masyarakat setempat. Berbeda halnya dengan konsep transformatif, yang mengambil suatu hal (budaya, pemikiran, gagasan) dari luar tetapi dilakukan secara kritis dan adaptif dengan memperhatikan tradisi dan kondisi masyarakat bersangkutan. 
Powers, David S. Studies in Qur'an and Hadith, The Formation of Islamic Law of Inheritance. Berkeley: University of California Press, 1986.

Susilaningsih dan Agus M. Najib, Kesetaraan Gender di Perguruan Tinggi Islam. Yogyakarta: PSW UIN-Mc Gill IISEP, 2004.

Umar, Nasaruddin. Argumen Kesetaraan Gender: Perspektif al-Qur'ân. Jakarta: Paramadina, 2001.

-------. “Kajian Kritis terhadap Ayat-ayat Gender (Pendekatan Hermeneutik)", dalam Lathiful Khuluq (ed), Rekonstruksi Metodologis Wacana Kesetaraan Gender dalam Islam. Yogyakarta: PSW UIN Sunan Kalijaga-ICIHEP-Pustaka Pelajar, 2002.

--------. “Metode Penelitian Berperspektif Gender tentang Literatur Islam", dalam Lathiful Khuluq (ed.), Rekonstruksi Metodologis Wacana Kesetaraan Gender dalam Islam. Yogyakarta: PSW UIN Sunan Kalijaga ICIHEP Pustaka pelajar, 2002.

Walther, Wiebke. Women in Islam; From Medieval to Modern Times. New York: Markus Wiener Publishing, 1993 